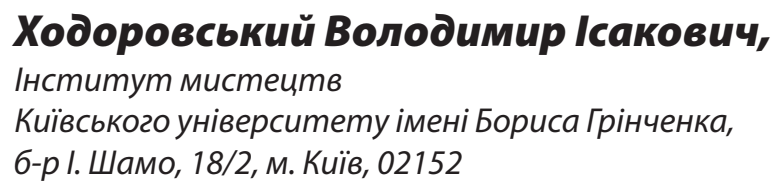

\title{
ОСОБЛИВОСТІ
}

ІНСТРУМЕНТАЛЬНО-ВИКОНАВСЬКОӦ
ПІДГОТОВКИ МАЙБУТНЬОГО ВЧИТЕЛЯ
МУЗИЧНОГО МИСТЕЦТВА НА ЗАНЯТТЯХ
КОНЦЕРТМЕЙСТЕРСЬКОГО КЛАСУ

У статті окреслено одну з актуальних проблем сучасної музично-педагогічної освіти - концертмейстерську підготовку майбутнього вчителя музичного мистецтва. Автор статmі висвітлює особливості занять концертмейстерського класу, на яких майбутній вчитель музики отримує комплекс знань, умінь та навичок, необхідних для подальшої успішної професійної діяльHості.

Ключові слова: інструментально-виконавська підготовка, концертмейстерські вміння, вчитель музичного мистецтва.

\section{Ходоровский В.И.}

Особенности инструментально-исполнительской подготовки будущего учителя музыкального искусства на занятиях концертмейстерского класса

В статье очерчена одна из наиболее актуальных проблем современного музыкально-педагогического образования - кончертмейстерская подготовка будущего учителя музыкального искусства. Автор статьи освещает особенности занятий концертмейстерского класса, на которых будущий учитель музыки получает комплекс знаний, умений и навыков, необходимых для дальнейшей успешной профессиональной деятельности.

Ключевые слова: инструментально-исполнительская подготовка, концертмейстерские умения, учитель музыкального искусства.

\section{Khodorovskyi V.I.}

The features of instrumental and performance training of future music teacher at concertmaster classes

The article presents one of the most current problems of modern music education concerning concertmaster training of students in higher education institutions of arts as one of the priority components of their future profession. The author of the article notes that music lessons in secondary school encourage teacher to the active manifestation not only of music and performing skills, but willingness to perform concertmaster job at a high professional level. A wide range of music teacher's concertmaster activities results in a whole set of his professional skills such as: coordinating teacher's performance activity with the soloist, the ability to read musical scores sheet, edit it, transpose the music material, pick accompaniment, if necessary, simplify or complicate maintenance, perform own song accompaniment etc. In light of this, the weight of the concertmaster classes increases, which acquires the status of primary professional development of future expert.

The author of the article highlights the features of instrumental and performance training of future music teacher at concertmaster classes and exposes potential possibilities of students' music and performance development during these classes, in particular, development of future music teachers' skills and abilities that are unique for concertmaster activities. The author points out such skills as: ability to accompany own singing, combine accompaniment while singing a soloist party, simplify or complicate the texture of musical accompaniment, read three rows of musical scores sheet, transpose music in connection with 
tessitura capabilities of performers, pick the melody and detailed accompaniment to it, ensemble skills, etc. The article states that concertmaster classes allow future music teachers to master necessary knowledge for future professional activity and skills and to fill the performance store with works of school repertoire. Key words: instrumental and performance training, concertmaster skills, music teacher.

B ступ. Актуальним для сучасної музичної педагогіки досі залишається питання пошуку шляхів удосконалення професійної підготовки майбутніх вчителів музичного мистецтва, зокрема інструментально-виконавської. У цьому контексті зростає значущість концертмейстерської підготовки як однієї з пріоритетних складових діяльності майбутніх фахівців. Після закінчення вищого навчального закладу більшість 3 них поряд 3 педагогічною діяльністю продовжують активно стверджуватись як виконавці-інструменталісти, здебільшого через концертмейстерську роботу: як акомпаніатори вокалістів, інструменталістів, вокально-хорових колективів тощо. Отже, концертмейстерська підготовка має велике значення для майбутнього професійного становлення вчителів музичного мистецтва, тому потребує розгляду особливостей ії здійснення.

Огляд літератури, концептуальних рамок, гіпотез тощо. Проблемі концертмейстерської діяльності присвячено праці М. Крючкова, $€$. Шендеровича, Дж. Мура. Вони містять багато корисної інформації щодо розвитку навичок читання 3 аркуша, транспонування, ансамблевої гри. Серед сучасних дослідників означеної проблеми варто назвати таких науковців та виконавців-концертмейстерів, як М. Моісєєва, Т. Молчанова, С. Саварі, А. Філяєва. Проблема розвитку навичок читання 3 аркуша знайшла своє відображення в працях Т. Воскресенської, К. Кучакевич, а навичок вокального акомпанементу - в роботах О. Люблінського, В. Подольської, М. Смірнова. У дослідженнях Фу Сяоцзин розкрито феномен музичного часу у діяльності концертмейстера.

Аналіз наукових досліджень дає змогу стверджувати, що особливості інструментальновиконавської підготовки майбутнього вчителя музики на заняттях концертмейстерського класу не мають належного висвітлення та наукового обгрунтування, що й визначило мету статті.

Методологія дослідження грунтується на загальнотеоретичних та методологічних положеннях філософії, психології та педагогіки щодо інструментально-виконавської підготовки майбутнього вчителя музичного мистецтва.

Мета статті - розглянути та проаналізувати особливості інструментально-виконавської підготовки майбутнього вчителя музичного мистецтва в концертмейстерському класі.
Результати дослідження та обговорення. У сучасній педагогічній науці під інструментально-виконавською підготовкою вчителя музичного мистецтва розуміють процес становлення музиканта, який володіє раціональними способами роботи 3 інструментом, грамотно читає текст музичного твору та вміє ретельно продумувати власну інтерпретацію, синтезуючи різні виконавські традиції.

Сьогоднішня інструментально-виконавська підготовка майбутнього вчителя музичного мистецтва забезпечується комплексом дисциплін інструментально-виконавського циклу (основний музичний інструмент, концертмейстерський клас, акомпанемент та імпровізація, додатковий інструмент) та передбачає володіння такими видами діяльності: сольне виконання творів, самостійна робота над музичними творами, акомпанування, читання з аркуша, транспонування, гра в ансамблі, творче музикування [1].

Професія вчителя музичного мистецтва, що характеризується різноплановістю й універсальністю, висуває високі вимоги щодо рівня інструментально-виконавської підготовки майбутнього фахівця, надзвичайне місце в якій належить досконалому володінню музичним інструментом. Відповідно до програмних вимог, під час викладання уроків музики в школі вчителеві доводиться не лише виконувати твори для прослуховування, але й акомпанувати під власний спів, добирати акомпанемент, транспонувати пісні у зручну для дитячих голосів тональність, акомпанувати вокально-хоровим колективам тощо, тобто разом із музично-виконавськими здібностями активно проявляти концертмейстерську майстерність. Такий широкий діапазон концертмейстерських дій учителя музичного мистецтва зумовлює наявність у нього цілого комплексу відповідних умінь, а саме: координування своїх виконавських дій із солістом, спроможність читати нотний текст 3 аркуша, редагувати його, транспонувати музичний матеріал, добирати акомпанемент на слух, при потребі спрощувати супровід або ускладнювати, виконувати пісню під власний супровід тощо. Саме тому стає зрозумілим, яку роль відіграють заняття в концертмейстерському класі для успішного й ефективного оволодіння майбутньою професією вчителя музичного мистецтва.

На жаль, незважаючи на значущість дисципліни «Концертмейстерський клас», в навчальному процесі ій не завжди приділяється 
достатньо уваги. Причини цього криються як у прагненні деяких педагогів скрупульозно відпрацювати зі студентами основні твори програми, так і в ігноруванні студентами можливості отримання нового концертмейстерського досвіду через недостатнє усвідомлення його вагомості для формування готовності до практичної діяльності в школі.

3 огляду на це хочеться наголосити на деяких особливостях інструментально-виконавської підготовки на заняттях концертмейстерського класу та можливостях, які вони надають. По-перше, на таких заняттях закладається притаманне лише концертмейстерській діяльності уміння акомпанувати (від $\oint p$. accompagnement, accompagner супроводжувати), тобто виконувати роль інструментального супроводу. У ході занять з означеної дисципліни студент отримує знання щодо особливостей акомпанування дитячому голосу або вокально-хоровому колективу; розуміння партії супроводу як художньо рівноцінної частини твору, що сприяє розкриттю його змісту; специфіки акомпанементу вокальних та інструментальних творів; особливостей поетичного тексту, взаємозв'язку слова зі звуком тощо. Поряд із цим відбувається формування навичок акомпанування власному співу, поєднання акомпанементу з одночасним наспівуванням партії соліста, спрощення чи ускладнення фактури музичного супроводу, умінь слідувати за динамічними та агогічними намірами соліста тощо [2].

По-друге, така необхідна якість музиканта, як уміння читати нотний текст з аркуша під час концертмейстерської роботи набуває специфічного характеру. Ця специфіка виявляється насамперед у тому, що концертмейстер (на відміну від соліставиконавця) повинен охопити одразу три рядки нотного тексту, який має виконати. Тобто одночасне бачення партії музичного супроводу та партії соліста $€$ обов'язковим для концертмейстерської діяльності. Процес набуття такого уміння достатньо складний і потребує систематичного тренування, спрямованого на формування навичок швидкої орієнтації в нотному тексті (охоплення напрямку мелодичної лінії, ритмічного малюнка, гармонічного плану музичного твору, особливостей типу фактури, основних напрямів динамічного, темпового розвитку твору тощо), здатності передбачати логіку розвитку музичної думки й ії емоційно-образного змісту, відпрацювання навичок гри без упину, не виявляючи затримок і зупинок в тексті тощо [7]. Досконале володіння означеними уміннями та навичками дасть змогу майбутньому вчителеві музичного мистецтва без тривалої попередньої підготовки, лише переглядаючи очима нотний текст, чітко уявляти кінцевий звуковий результат виконання.
По-третє, жодна 3 дисциплін інструментально-виконавського циклу, окрім концертмейстерського класу, не сприяє формуванню у студентів навичок транспонування (від латин. transponieren - переставляти, переміщувати), які виявляються у здатності змінювати оригінальну тональність музичного твору в залежності від теситурних можливостей соліста-виконавця. Сумісна робота викладача зі студентом у цьому напрямку спрямована на актуалізацію знань основних аплікатурних принципів гам, акордів, арпеджіо, активізацію музично-слухового самоконтролю, пам'яті та уваги студента задля швидкого перенесення фактурних і гармонічних особливостей в іншу тональність.

Наступна особливість занять концертмейстерського класу полягає у підготовці студента до гри в ансамблі. Як свідчить практика, ансамблеві завдання іноді стають занадто складними навіть для добре підготовлених студентів. Є.М. Шендерович причину цього вбачає в тому, що концертмейстер не розуміє специфіки ансамблевого виконання зі співаком, часом не бачить партії соліста (верхнього рядка нотного стану), не враховує органічних пауз, особливостей дихання, не знає законів будови вокальної фрази [7]. Врахування цих моментів, а також розвиток уміння грати синхронно з партнером, інтуїтивно відчувати його задум і художні наміри, підлаштовуватися під темпові, динамічні зміни, утримувати ритмічний баланс та узгоджувати 3 ним виконавський план музичного твору стане запорукою успіху концертмейстерської діяльності.

Особливого значення для майбутнього вчителя музичного мистецтва набуває вміння добирати на слух, досконале володіння яким дає змогу розширювати репертуарні межі музичнопісенного матеріалу за рахунок додавання нових популярних пісень і мелодій, не зафіксованих у нотах.

Висновки та перспективи подальших досліджень. Резюмуючи все вищесказане, хотілося 6 відзначити, що обсяг публікації дає змогу лише оглядово зупинитися на основних моментах, які відбуваються на заняттях концертмейстерського класу. Особливість таких занять полягає у допомозі студентові вирішувати завдання, що стоять перед концертмейстером i зобов'язують його бути широко ерудованим музикантом, спроможним моментально орієнтуватися в нотному тексті, транспонувати й добирати на слух пісні, сприяти ансамблевій узгодженості між партнерами. Означені заняття являють собою обов'язкову ланку в інструментально-виконавській підготовці майбутнього вчителя музичного мистецтва, яка уможливлює оволодіння першочерговими професійними вміннями та навичками. 


\section{ДЖЕРЕЛА}

1. Арчажникова Л.Г. Профессия - учитель музыки. Книга для учителя / Л.Г. Арчажникова. - М. : Просвещение, 1984. - 111 с.

2. Карпенко Т.П. Підготовка майбутніх учителів музики до концертмейстерської діяльності / Т.П. Карпенко // Педагогічна освіта: теорія і практика : зб. наук. пр. - Кам'янець-Подільський : Видавець ПП Зволейко Д.Г., 2010. - Вип. 4. - С. 286-293.

3. Моісєєва М.А. Спільна музично-виконавська діяльність як засіб формування професійних якостей учителя музики (на матеріалі концертмейстерського класу) : автореф. дис. ... канд. пед. наук : 13.00.02 / М.A. Моісєєва. - К., 1998. - 16 с.

4. Молчанова Т. 3 історії ансамблевого музикування / Т. Молчанова. - Л. : ЛДМА, Сполом, 2005. $160 \mathrm{c}$.

5. Мур Дж. Певец и аккомпаниатор. Воспоминания. Размышления о музыке / Дж. Мур. - М. : Радуга, 1987. - 432 с.

6. Островская E.A. Психологические аспекты деятельности концертмейстера в музыкальнообразовательной сфере инструментального исполнительства : моногр. / Е.А. Островская ; под ред. А.И. Демченко. - Рязань, 2012. - 200 с.

7. Шендерович E.M. В концертмейстерском классе. Размышления педагога / Е.М. Шендерович. - М., 1996. - 207 c.

\section{REFERENCES}

1. Archazhnikova L.G. Professiia - uchitel muzyki [Profession - Music Teacher]. Kniga dlia uchitelia / L.G. Archazhnikova. - M. : Procveschenie, 1984. - 111s.

2. Karpenko T.P. Pidhotovka maibutnikh uchiteliv muzyku do kontsertmeisterskoi diialnosti [Future Music Teachers Training for Concertmaster Activities]. T.P. Karpenko // Pedahohichna osvita: teoriha i praktyka : zb. nauk. prats. - Kamianets-Podilskyi : Vydavets PP Zvoleiko D.H., 2010. - Vyp. 4. - S. 286-293.

3. Moisieieva M.A. Spilna muzychno-vykonavska diialnist yak zasib formuvannia profesiinykh yakostei uchytelia muzyky (na materiali kontsertmeisterskoho klasu) [Joint Musical Performance as a Means of Forming Professional Qualities of Teacher of Music (on the material of the concertmaster class)]: avtoref. dys... kand. ped. nauk: 13.00.02 / Moisieieva Marharyta Arkadiivna. - K., 1998. - 16 s.

4. Molchanova T. Z istorii ansamblevoho muzykuvannia [From History of Ensemble Music]. T. Molchanova.Lviv : LDMA, Spolom, 2005. - 160 s.

5. Mur Dzh. Pevets i akkompaniator. Vospominaniia. Razmyshleniia o muzyke [Singer and Accompanist. The Performance of Fifty Songs]. Gerald. Moore. - M. : Raduga, 1987. — $432 \mathrm{~s}$.

6. Ostrovskaia E.A. Psihologicheskie aspekty deiatelnosti kontsertmeistera v muzykalno-obrazovatelnoi sfere instrumentalnogo ispolnitelstva[Psychological Aspects of Accompanist's Activity in Musical and Educational Sphere of Instrumental Performance: monograph] : monografiia / E.A. Ostrovskaia, pod redaktsiei A.I. Demchenko. - Riazan. - 2012. - 200 s.

7. Shenderovich E.M. V kontsertmeisterskom klasse. Razmyshleniia pedagoga [At Concertmasters' Classes. Reflections of Teacher]. E.M. Shenderovich. - M. - 1996. - 207 s. 